\title{
Involvement of ethylene, oxidative stress and lipid-derived signals in cadmium-induced programmed cell death in tomato suspension cells
}

\author{
Elena Iakimova*1, Veneta Kapchina-Toteva², Anke de Jong3, \\ Atanas Atanassov ${ }^{1}$ and Ernst Woltering ${ }^{3}$
}

\author{
Address: ${ }^{1}$ AgroBioInstitute, Sofia, Bulgaria, ${ }^{2}$ Faculty of Biology, University of Sofia, Bulgaria and ${ }^{3}$ Agrotechnology and Food Innovations, \\ Wageningen University and Research Center, Wageningen, The Netherlands \\ Email: Elena Iakimova* - elena_iakimova@abi.bg \\ * Corresponding author
}

from Cell Biology of Nitric Oxide and Cell Death in Plants

Yalta, Ukraine, 8-II September 2004

Published: 3I May 2005

BMC Plant Biology 2005, 5(Suppl I):S19 doi:10.1186/I47I-2229-5-SI-SI9

\section{Backgraund}

Extensive research is ongoing looking for the characterisation of programmed cell death (PCD) in plants involving pathogen attack, chemical elicitation and abiotic inducers, but there are still limited reports on the role of heavy metals in PCD induction and little is known about cadmium-triggered signal transduction in plant systems. Contamination of biosphere with heavy metals has hazardous effect on agricultural crops and human health. In animal models, cadmium intoxication occurs through apoptosis appearing by apoptotic phenotype and an oxidative stress is involved in the mechanism of $\mathrm{Cd}$ action. The goal of this present work was to investigate if programmed cell death occurs in cadmium-treated tomato suspension cells; to identify some of the biochemical processes contributing to the signal transduction pathway(s) involved in cadmium toxicity; to investigate the role of oxidative stress (hydrogen peroxide), ethylene and lipid-derived signals and to look for similarities between cadmium- and camptothecin-induced cell death.

\section{Materials and methods}

The experiments were undertaken with tomato suspension cells, line Msk8. Specific inhibitors of different biochemical steps were administrated simultaneously with either $\mathrm{CdSO}_{4}$ or topoisomerase-1 inhibitor camptothecin (CPT). Cell viability (FDA staining of the viable cells) was determined after 24 hours and the dynamics of $\mathrm{H}_{2} \mathrm{O}_{2}$ production was measured by chemiluminescence in a ferricyanide-catalised oxidation of luminol. Specific caspase peptide inhibitors, antioxidants, NADPH oxidase inhibi- tors, calcium channel blockers, inhibitors of phospholipid cycle, protein kinase inhibitor and ethylene blockers were tested. Ethylene was applied during $24 \mathrm{~h}$ in concentrations up to $100 \mathrm{ppm}$ in the head space. For details on methodology see $[1,2]$.

\section{Results}

The human caspase-1 inhibitor Ac-YVAD-CMK and the broad range caspase inhibitor Z-Asp- $\mathrm{CH}_{2}-\mathrm{DCB}$, abolished the cell death of Cd-treated and CPT-treated cells (See Table 1). This strongly suggests that the cell death pathway that is induced by cadmium employs caspase-like proteases and gives a reason to assume that in tomato suspension cells Cd-triggered cell death most probably resembles features of programmed cell death. The amount of hydrogen peroxide increased in response to Cd and CPT. Efficient inhibition of cell death occurred at the application of antioxidants and calcium channel blocker (See Table 1 ). The inhibition of NADPH oxidase by imidazole, quercetin and kaempferol significantly reduced the percentage of dead cells.

Treatments with ethylene further decreased both Cd- and CPT-reduced cell viability. Comparative experiments with Cd- or CPT-treated cells revealed an analogy in cell response to the ethylene inhibitor AVG (See Table 2). AVG greatly reduced the cell death that was enhanced in response to Cd or CPT. An increase of endogenous ethylene production (measured by laser photoacoustics) occurred in cadmium-treated cells. The data are a clear demonstration of ethylene involvement in Cd- and CPT- 
Table I: Effect of caspase peptide inhibitors, antioxidants (ascorbic acid, catalase, spermine) and calcium channel blocker $\mathrm{LaCl}_{3}$ on viability of CPT- or Cd-treated tomato suspension cells

\begin{tabular}{|c|c|}
\hline Chemicals & Cell viability (\%) \\
\hline Control & 97.5 \\
\hline СРТ $5 \mu \mathrm{M}$ & 72.5 \\
\hline $\mathrm{CdSO}_{4} \mathrm{IOO} \mu \mathrm{M}$ & 65.0 \\
\hline CPT $\mu M+$ Ac-YVAD-CMK $100 \mu M$ & 92.5 \\
\hline $\mathrm{CdSO}_{4} 100 \mu \mathrm{M}+$ Ac-YVAD-CMK $100 \mu \mathrm{M}$ & 94.0 \\
\hline $\mathrm{CdSO}_{4} 100 \mu \mathrm{M}+\mathrm{Z}$-asp-CH2-DCB $100 \mu \mathrm{M}$ & 91.5 \\
\hline CPT $5 \mu \mathrm{M}+$ ascorbic acid $100 \mu \mathrm{M}$ & 93.5 \\
\hline CPT $5 \mu \mathrm{M}+$ catalase 10 Units $/ \mathrm{ml}$ & 91.5 \\
\hline CPT $5 \mu \mathrm{M}+$ spermine $100 \mu \mathrm{M}$ & 88.5 \\
\hline $\mathrm{CdSO}_{4} \mathrm{I} 00 \mu \mathrm{M}+$ ascorbic acid $100 \mu \mathrm{M}$ & 92.5 \\
\hline $\mathrm{CdSO}_{4} 100 \mu \mathrm{M}+$ catalase 10 Units $/ \mathrm{ml}$ & 91.5 \\
\hline $\mathrm{CdSO}_{4} 100 \mu \mathrm{M}+$ spermine $100 \mu \mathrm{M}$ & 88.2 \\
\hline $\mathrm{CPT}+5 \mu \mathrm{M}+\mathrm{LaCl}_{3} \mathrm{I} 00 \mu \mathrm{M}$ & 95.0 \\
\hline $\mathrm{CdSO}_{4} 100 \mu \mathrm{M}+\mathrm{LaCl}_{3} \mathrm{I} 00 \mu \mathrm{M}$ & 94.5 \\
\hline
\end{tabular}

Table 2: Effect of ethylene and ethylene inhibitor AVG on cell viability of CPT and cadmium treated tomato cell suspension

\begin{tabular}{|c|c|}
\hline Chemicals & Cell viability (\%) \\
\hline Control & 95 \\
\hline СРТ $5 \mu \mathrm{M}$ & 72 \\
\hline $\mathrm{CdSO}_{4} 100 \mu \mathrm{M}$ & 68 \\
\hline AVG $10 \mu \mathrm{M}$ & 98 \\
\hline Ethylene (Eth) $100 \mu \mathrm{L} / \mathrm{L}$ & 95 \\
\hline CPT $5 \mu \mathrm{M}+$ Eth $100 \mu \mathrm{L} / \mathrm{L}$ & 50 \\
\hline $\mathrm{CdSO}_{4} 100 \mu \mathrm{M}+$ Eth $100 \mu \mathrm{L} / \mathrm{L}$ & 48 \\
\hline CPT $5 \mu \mathrm{M}+$ AVG $10 \mu \mathrm{M}$ & 90 \\
\hline $\mathrm{CdSO}_{4} 100 \mu \mathrm{M}+\mathrm{AVG} 10 \mu \mathrm{M}$ & 86 \\
\hline CPT $5 \mu \mathrm{M}+$ AVG $10 \mu \mathrm{M}+$ Eth $100 \mu \mathrm{L} / \mathrm{L}$ & 38 \\
\hline $\mathrm{CdSO}_{4} 100 \mu \mathrm{M}+\mathrm{AVG} 10 \mu \mathrm{M}+$ Eth $100 \mu \mathrm{L} / \mathrm{L}$ & 49 \\
\hline
\end{tabular}

triggered cell death. Administration of $\mathrm{IP}_{3}$ cycle inhibitors showed a strong inhibition to Cd-induced cell death.

\section{Conclusion}

Evidence is accumulating that caspase-like cysteine proteases showing functional similarity to animal caspases, participate in the programmed cell death in plants. In addition to discoveries that caspase-like proteases are involved in cell death in response to pathogen invasion, abiotic stresses and chemical elicitation, our data show that cell death induced by cadmium is also a form of programmed cell death mediated by caspase-like proteases. We have established a key role of hydrogen peroxide and calcium in cadmium-induced apoptotic cell death and have demonstrated that oxidative stress is associated with both cadmium and camptothecin-triggered cell death. We have also shown that polyamine spermine can effectively preserve the cell viability at conditions of chemical stress.

Ethylene was found to be an important mediator of plant cell death. The finding that ethylene greatly stimulated cadmium-induced cell death and that cadmium treatment enhanced endogenous ethylene production indicated that ethylene participates in cadmium-induced cell death in tomato suspension cells. The application of specific inhibitors of phospholipase C, phospholipase D, inositolphosphate monophosphatase, inositol-3-phosphate kinase and phosphatidic acid caused considerable decrease of Cd-stimulated cell death and are the first more detailed evidence that Cd-triggered cell death in plants involves the phospholipid pathway.

Collectively, the cell response to cadmium elicitation and the inhibitors indicate that Cd-triggered cell death is analogous to cell death in response to CPT treatment [1$4]$ and involves caspase-like proteases, oxidative stress and ethylene. Cd-induced cell death in plant cells exhibits similarities to HR [5] and cell death induced by known apoptosis inducing chemicals and to its effect in animal systems.

\section{Acknowledgements}

Elena lakimova and Veneta Kapchina-Toteva were supported by STSM grants (COST Action 844) and FP5 IHP LSF grants. Authors are thankful to France Harren and Luc-Jan Laarhoven for the assistance with the laser photoacoustics.

\section{References}

I. de Jong A, Yakimova E, Hoeberichts F, Maximova E, Woltering E: Chemical-induced apoptotic cell death in tomato cells: Involvement of caspase-like proteases. Planta 2000, $211: 656-662$.

2. de Jong A, Yakimova E, Kapchina $V$, Woltering $E$ : A critical role of ethylene in hydrogen peroxide release during programmed cell death in tomato suspension cells. Planta 2002, 21 4:537-545.

3. Woltering E, van der Bent A, Hoeberichts F: Do plant caspases exist? Plant Physiol 2002, I30: I764-1769.

4. Woltering E, de Jong A, lakimova E, Kapchina V, Hoeberichts F: Ethylene: Mediator of oxidative stress and programmed cell death in plants. In Biology and Biotechnology of the Plant Hormone Ethylene III Edited by: Vendrell. IOS Press; 2003:3 15-323.

5. lakimova E, Batchvarova R, Kapchina-Toteva V, Popov T, Atanassov $A$, Woltering E: Inhibition of apoptotic cell death induced by Pseudomonas syringae pv. tabaci and mycotoxin Fumonisin B I. Biotech \&Biotech Eq 2004, I 8:34-46. 